\title{
Effects of epsilon-aminocaproic acid on fertility in the rabbit $\dagger$
}

\author{
A. T. L. Andrade, S. T. Shaw, Jr*, M. O. Guerra and D. E. Aaronson \\ The Center for Biology of Reproduction, Federal University of Juiz de Fora, Juiz de Fora, Brazil \\ and the * Departments of Obstetrics and Gynecology, and Pathology, \\ University of Southern California School of Medicine, \\ 1321 North Mission Road, Los Angeles, California 90033, U.S.A.
}

\begin{abstract}
Summary. Administration of epsilon-aminocaproic acid, a fibrinolytic inhibitor, either orally or from an impregnated IUD, had no effect on numbers of implanted embryos, their viability, or their diameters at Day 10 of pregnancy.
\end{abstract}

\section{Introduction}

Intrauterine contraceptive devices (IUDs) have been shown to increase fibrinolytic activity in the uterus of monkeys (Shaw, Cihak \& Moyer, 1970), and in man, rabbits, and rats fitted with IUDs (Larsson, Liedholm, Sjöberg \& Åstedt, 1974; Larsson, Liedholm \& Åstedt, 1975; Liedholm \& Sjöberg, 1977). A possible role for the fibrinolytic system in producing uterine haemorrhage associated with the use of IUDs has been suggested (Shaw \& Moyer, 1974). Systemic antifibrinolytic therapy has proved beneficial for some patients with menorrhagia (Nilsson \& Björkman, 1965; Nilsson \& Rybo, 1965, 1971; Vermylen, Verhaegen-Duclerq, Verstraete \& Fierens, 1968; Callender, Warner \& Cope, 1970) and those with uterine haemorrhage associated with IUDs (Weström \& Bengtsson, 1970; Kasonde \& Bonnar, 1975). Uterine haemorrhage was less in monkeys fitted with IUDs impregnated with the fibrinolytic inhibitor, epsilon-aminocaproic acid (EACA), than in those with non-impregnated devices (Shaw, Moyer, Aaronson, Underwood \& Forino, 1975). These findings suggest that the effects of intrauterine medication with fibrinolytic inhibitors, for the purpose of controlling endometrial haemorrhage, merit further study.

Preimplantation blastocysts of rabbits exhibit proteolytic activity when incubated on gelatin films (Denker \& Hafez, 1975). Rat ova have also been shown, by histochemical studies, to have fibrinolytic activity during oviductal transport but not at implantation and the rat decidua exhibits powerful inhibitory activity directed against fibrinolytic activators (Liedholm \& Åstedt, 1975). These findings suggest that enhancement of fibrinolysis could be a prime contraceptive action of the IUD. Consequently, the control of IUD-induced bleeding with fibrinolytic inhibitors could facilitate the implantation mechanism and perhaps nullify the contraceptive action of the IUD. However, McNicol, Fletcher, Alkjaersig \& Sherry (1962) have shown that EACA inhibits the incorporation of lysine into cellular protein, and therefore high EACA levels in uterine fluid could alter blastocyst development. and implantation in a way which could promote infertility.

In the present investigation, the effects of EACA on pregnancy in rabbits with and without IUDs were studied to see if EACA altered fertility or IUD contraception.

\section{Materials and Methods}

\section{Experiment A: animals without IUDs}

Twenty-four (24) virgin 6-month-old rabbits weighing from 2500 to $3400 \mathrm{~g}$ received an intramuscular injection of 25 i.u. hCG upon arrival, and were kept for 3 weeks before being naturally mated with fertile bucks (Day 0 of pregnancy). Seventeen (17) rabbits were given an oral dose of epsilon-aminocaproic acid (6-amino-hexanoic acid: CalBiochem, Los Angeles, California) four times

$\dagger$ Reprint requests to Dr S. T. Shaw, Jr. 
a day so that the total daily dose was $357 \mathrm{mg} / \mathrm{kg}$ body weight. This dose was selected because of the known therapeutic effect in women of the same oral dosage schedule (McNicol \& Douglas, 1972). The animals were treated with EACA on Days 1-5 of pregnancy inclusive (Group 1, 9 rabbits) or on Days 1-9 inclusive (Group 2, 8 rabbits). The other 7 rabbits were similarly handled but received no EACA. All animals were killed on Day 10.

To verify that the drug was present in the blood at an effective level, blood samples $(1.5 \mathrm{ml})$ were withdrawn daily from all 24 rabbits throughout the experimental period and tested for the time taken to inhibit the lysis of a streptokinase-activated euglobulin clot. For this test, $0.5 \mathrm{ml}$ rabbit serum was added to $0.5 \mathrm{ml}$ of a pooled human plasma euglobulin preparation, $0.02 \mathrm{ml}$ streptokinase $(2.5$ units $)$ and $0.01 \mathrm{ml}$ bovine thrombin ( $10 \mathrm{NIH}$ units). The preparation was mixed and incubated at $37^{\circ} \mathrm{C}$, and examined every $5 \mathrm{~min}$ during the first hour, and at every $60 \mathrm{~min}$ thereafter, to see if the resulting clot had dissolved.

\section{Experiment B: animals with IUDs}

IUDs. Cylindrical IUDs, with and without EACA, were made of silicone rubber (Silastic ${ }^{\text {TM }} 382$ medical grade elastomer: Dow Corning, Midland, Michigan). Each device was $1.9 \mathrm{~mm}$ in diameter and $20 \mathrm{~mm}$ long, and was soaked in aqueous benzalkonium hydrochloride $(1: 12000)$ and washed with sterile saline before insertion. The IUDs were impregnated with $4 \mathrm{mg}$ EACA by mixing dry EACA with liquid monomeric Silastic ${ }^{\mathrm{TM}}$ diluted in thinner (200 Electronic Fluid: Dow Corning) and polymerizing with stannous octoate.

The devices were tested in vitro and in vivo for drug release. The elution rate in vitro was evaluated by soaking whole devices in distilled water in a shaking water bath at $37^{\circ} \mathrm{C}$. The water $(20 \mathrm{ml}$ per device) was changed daily for 10 days and analysed for EACA concentration by a modified ninhydrin technique (Paik \& Kim, 1964). Release in vivo was determined by removing devices from rabbits after 2, 5 and 10 days in utero. The EACA remaining in each device was determined by elution to exhaustion in vitro and measurement of the eluates by the modified ninhydrin method. The amount of EACA completely eluted was subtracted from the original amount per device $(4 \mathrm{mg})$ to give the quantity released in utero at the three intervals tested.

Experiments. Rabbits were laparotomized under pentobarbital anaesthesia and IUDs were inserted through a 2-mm stab wound into the mid-portion of each uterine horn and fixed to the uterine wall by a 5-0 silk suture. After at least 5 days, the rabbits were naturally mated to fertile bucks (Day 0 ) and killed on Day 10. Non-impregnated (control) IUDs were placed in both uterine horns of 17 rabbits and 9 of these were treated systemically with EACA as described for animals in Group A-2. In another 20 rabbits, a control device was inserted into one uterine horn and an experimental (EACA) device was inserted into the other horn of each animal.

At autopsy the entire genital tract was removed from all the animals tested and the corpora lutea (CL) and the implantation sites were counted on each side. All implantation sites were dissected under a microscope and viability of the embryos was assessed by examining for embryonic heart beats and structural abnormalities.

The results were analysed statistically by $\chi^{2}$-tests with continuity correction for the implantation rates and by Student's $t$ test for the diameter of implantations. The probability level selected for significance was $5 \%$.

\section{Results}

As shown in Table 1, the euglobulin clot lysis inhibition time increased from 20 to 50 min in controls to more than $6 \mathrm{~h}$ in all the EACA-treated animals, indicating that the oral treatment of the rabbits led to considerable fibrinolytic activity in the blood. The effects of the two treatment regimens are shown in Table 2. There was no alteration $(P>0.05)$ of the implantation rates, the number of viable implantations or their diameters at Day 10 of pregnancy in any of the groups.

Oral treatment with EACA of rabbits fitted bilaterally with control IUDs had no statistically 
Table 1. The time for serum from control and EACA-treated rabbits to inhibit lysis of an activated euglobulin clot

\begin{tabular}{cccc}
\hline $\begin{array}{c}\text { Day } \\
\text { after } \\
\text { mating }\end{array}$ & $\begin{array}{c}\text { Controls } \\
(\mathrm{N}=7)\end{array}$ & $\begin{array}{c}\text { Treatment } \\
\text { Days } 1-5 \\
(\mathrm{~N}=9)\end{array}$ & $\begin{array}{c}\text { Treatment } \\
\text { Days 1-9 } \\
(\mathrm{N}=8)\end{array}$ \\
\hline 0 & $25-40 \mathrm{~min}$ & $20-50 \mathrm{~min}$ & $25-45 \mathrm{~min}$ \\
1 & $30-45 \mathrm{~min}$ & $6->24 \mathrm{~h}$ & $6->24 \mathrm{~h}$ \\
2 & $25-45 \mathrm{~min}$ & $6->24 \mathrm{~h}$ & $6->24 \mathrm{~h}$ \\
3 & $30-40 \mathrm{~min}$ & $8->24 \mathrm{~h}$ & $8->24 \mathrm{~h}$ \\
4 & $25-45 \mathrm{~min}$ & $8->24 \mathrm{~h}$ & $8->24 \mathrm{~h}$ \\
5 & $25-45 \mathrm{~min}$ & $6->24 \mathrm{~h}$ & $6->24 \mathrm{~h}$ \\
6 & $30-45 \mathrm{~min}$ & - & $>24 \mathrm{~h}$ \\
7 & $25-40 \mathrm{~min}$ & - & $>24 \mathrm{~h}$ \\
8 & $20-40 \mathrm{~min}$ & - & $>24 \mathrm{~h}$ \\
9 & $30-45 \mathrm{~min}$ & - & $>24 \mathrm{~h}$ \\
10 & $25-45 \mathrm{~min}$ & - & $>24 \mathrm{~h}$ \\
\hline
\end{tabular}

Table 2. The effects of oral administration of EACA ( $357 \mathrm{mg} / \mathrm{kg}$ body weight/day) on the fertility of and implantation in rabbits killed on Day 10 after mating

\begin{tabular}{lccccc}
\hline \multicolumn{1}{c}{ Treatment } & $\begin{array}{c}\text { No. of } \\
\text { rabbits }\end{array}$ & $\begin{array}{c}\text { No. of } \\
\text { CL }\end{array}$ & $\begin{array}{c}\text { No. of } \\
\text { impantation } \\
\text { sites }(\%)\end{array}$ & $\begin{array}{c}\text { No. of } \\
\text { viable } \\
\text { implantation } \\
\text { sites }(\%)\end{array}$ & $\begin{array}{c}\text { Mean } \pm \text { s.e.m. } \\
\text { diam. of } \\
\text { implantation } \\
\text { site }(\mathrm{mm})^{*}\end{array}$ \\
\hline None (controls) & 7 & 55 & $51(92 \cdot 7)$ & $48(87 \cdot 3)$ & $16 \cdot 2 \pm 0 \cdot 3$ \\
EACA, Days 1-5 & 9 & 77 & $73(94 \cdot 8)$ & $70(90 \cdot 9)$ & $16 \cdot 5 \pm 0 \cdot 2$ \\
EACA, Days 1-9 & 8 & 71 & $68(95 \cdot 8)$ & $66(93 \cdot 0)$ & $16 \cdot 6 \pm 0 \cdot 2$ \\
\hline
\end{tabular}

* The value for each site was the average of the two greatest diameters.

significant effect on fertility. In the 8 control animals, the $65 \mathrm{CL}$ were associated with $44(67 \cdot 7 \%) \mathrm{im}$ plantations of which $35(53.8 \%)$ were viable, and in the 9 EACA-treated animals the corresponding figures were $79 \mathrm{CL}, 56(71 \%)$ implantations and $45(57 \%)$ viable embryos.

The elution rate of EACA from impregnated IUDs was $15 \pm 5 \%$ (mean \pm s.e.m.) of the original $4 \mathrm{mg}$ in each device over the 10-day period. Release of EACA from IUDs in vivo was calculated to be $63 \%(2.5 \mathrm{mg})$; most of the release occurred during the first 2 days and a plateau was reached by the 5 th day. The much higher release rate found in utero than in vitro was most probably due to the more continuous exchange of uterine fluid than was possible in vitro, although the medium was changed daily, or to other differences in the rabbit uterine environment.

Comparison of the implantation rate and numbers of viable fetuses in each horn of rabbits with control and EACA-impregnated IUDs showed that there was no statistically significant difference. In the 20 horns with control IUDs there were 60 implantations ( 50 viable) associated with $92 \mathrm{CL}$, and in the contralateral, EACA-treated horns there were 51 implantation sites ( 45 viable) associated with $82 \mathrm{CL}$, giving $54.3 \%$ viable implantations in the control-IUD horns and $54.9 \%$ in the EACA-IUD uterine horns. The mean \pm s.e.m. diameters of the implantation sites in each group was $15.7 \pm 0.4 \mathrm{~mm}$ for the controls and $15 \cdot 6 \pm 0 \cdot 2 \mathrm{~mm}$ for the experimentals.

\section{Discussion}

Examination of the possibility that a fibrinolytic inhibitor, such as EACA, administered during the period of conception and nidation could enhance ovum implantation showed that oral treatment of rabbits with EACA gave effective systemic levels of fibrinolytic inhibition but did not cause any alterations in the number or size of implantations in naturally mated does. It may be impossible, however, to show an improvement by any treatment when control implantation rates are nearly $90 \%$. 
The fact that fertility was not lowered by oral EACA treatment indicated that EACA, possibly acting independently of its effect on fibrinolysis by inhibiting protein synthesis by the decidua or the embryo, had no significant effect on blastocyst development or implantation.

The effect of silicone rubber IUDs in the rabbit is to decrease implantation rates from about $90 \%$ to $50 \%$. EACA treatment of IUD-bearing rabbits, whether by a systemic or intrauterine route, also failed to show any differences in implantation rates or viability and size of implantations.

These findings in the rabbit suggest that the endometrial bleeding caused by IUDs in women may be controlled with IUDs impregnated with fibrinolytic inhibitors without impairing or enhancing the contraceptive effect of the devices.

This work was supported by grants from the World Health Organization and Ford Foundation.

\section{References}

Callender, S.T., Warner, G.T. \& Cope, E. (1970) Treatment of menorrhagia with tranexamic acid. A double-blind trial. Br. med. J. 4, 214-216.

Denker, H.W. \& Hafez, E.S.E. (1975) Proteases and implantation in the rabbit: role of trophoblast vs. uterine secretion. Cytobiologie 11, 101-109.

Kasonde, J.M. \& Bonnar, J. (1975) Aminocaproic acid and menstrual loss in women using intrauterine devices. Br. med. J. 4, 17-19.

Larsson, B., Liedholm, P. \& Åstedt, B. (1975) Effect of copper and plastic intrauterine devices on the fibrinolytic activity of the endometrium in the rat. Int. J. Fert. 20, 145-150.

LARSSON, B., LIEdholm, P., SJöberG, N.O. \& ÅsTedt, B(1974) Increased fibrinolytic activity in the endometrium of patients using copper-IUD. Contraception 9, 531-537.

LIedHolm, P. \& Ástedt, B. (1975) Fibrinolytic activity of the rat ovum, appearance during tubal passage and disappearance at impiantation. Int. J. Fert. 20, 24-26.

LIEDHOLM, P. \& SJöBeRg, N.O. (1977) Fibrinolytic activity in the rabbit uterus and its fluid with and without copper IUD. Contraception 15, 215-224.

McNicol, G.P. \& Douglas, A.S. (1972) Thrombolytic therapy and fibrinolytic inhibitors. In Human Blood Coagulation, Haemostasis and Thrombosis, Ch. 15. Ed. R. Biggs. Blackwell Scientific Publications, Oxford.

McNicol, G.P., Fletcher, A.P., Alkjaersig, N. \& SHERRY, S. (1962) The absorption distribution, and excretion of $\varepsilon$-aminocaproic acid following oral or intravenous administration to man.J.Lab. Clin. Med. 59, 15-24.
NilsSON. I.M. \& BJÖRKMAN, S.E. (1965) Experiences with $\varepsilon$-animocaproic acid ( $\varepsilon$-ACA) in the treatment of profuse menstruation. Acta med. scand. 177, 445-457.

Nilsson, L. \& RYBO, G. (1965) Treatment of menorrhagia with epsilon aminocaproic acid, Acta obstet. gynec. scand. 44, 467-473.

Nilsson, L. \& Rybo, G. (1971) Treatment of menorrhagia. Am.J. Obstet. Gynec. 110, 713-720.

PAIK, W.K. \& KIM, S. (1964) Colorimetric differentiation of $\alpha$ - and E-N-substituted lysine derivatives. Nature, Lond. 202, 793-794.

Shaw, S.T., JR \& Moyer, D.L. (1974) Problem bleeding with IUDs. In Intrauterine Devices-Development, Evaluation, and Program Implementation, pp. 99-103. Eds R. G. Wheeler, G. W. Duncan \& J. J. Speidel. Academic Press, New York.

Shaw, S.T., JR, Cihak, R.W. \& Moyer, D.L. (1970) Fibrin proteolysis in the monkey uterine cavity: variations with and without IUD. Nature, Lond. 228, 1097-1098.

Shaw, S.T., JR, Moyer, D.L., Aaronson, D.E., UNDERWOOD, J. \& FORINO, R.V. (1975) Intrauterine medication with epsilon aminocaproic acid. Effect on rhesus monkeys wearing intrauterine devices. Contraception 11, 395-407.

Vermylen, J., Verhaegen-DuclercQ, M.L., Verstraete, M. \& Fierens, F. (1968) A double blind study of the effect of tranexamic acid in essential menorrhagia. Thromb. Diath. haemorrh. 20, 583-587.

WESTRÖM, L. \& BeNGTSSON, L.P. (1970) Effect of tranexamic acid (AMCA) in menorrhagia with intrauterine contraceptive devices. J. Reprod. Med. 5, 154 161.

Received 10 June 1977 